\title{
PREVALENCE OF HEPATOPULMONARY SYNDROME IN PATIENTS WITH DECOMPENSATED CHRONIC LIVER DISEASE AND ITS IMPACT ON SHORT-TERM SURVIVAL
}

\author{
Palmireno Pinheiro FERREIRA ${ }^{1,2}$, Edmundo José Nasri CAMARA ${ }^{1}$, Rogério Luis Porto de PAULA ${ }^{1}$, \\ Cláudio Celestino ZOLLINGER ${ }^{1}$, Andréa Ribeiro CAVALCANTI ${ }^{1}$ and Paulo Lisboa BITTENCOURT ${ }^{1,2}$
}

\begin{abstract}
Background - Hepatopulmonary syndrome is reported to occur in $4 \%$ to $32 \%$ of the patients with chronic liver disease and is associated with poor liver function and shortened patient survival before and after liver transplantation. Aims - To assess the frequency of hepatopulmonary syndrome in Brazilian patients with decompensated chronic liver disease and to investigate its impact on patient survival. Methods - One hundred and thirty patients (101 males, mean age $61 \pm 12$ years) with decompensated chronic liver disease were evaluated for the presence of hepatopulmonary syndrome. The diagnosis of hepatopulmonary syndrome was considered in the presence of alveolar arterial oxygen gradient of more than $15 \mathrm{~mm} \mathrm{Hg}$ and of pulmonary vascular dilatation assessed by contrast enhanced echocardiography. Results - Hepatopulmonary syndrome was observed in $21(16 \%)$ patients. The presence of hepatopulmonary syndrome was significantly associated with severity of liver disease assessed by the MELD (Model for End-Stage Liver Disease) score, but not with in hospital mortality after admission due to decompensated chronic liver disease. Conclusions - Hepatopulmonary syndrome occurs in $16 \%$ of patients with chronic liver disease and is associated with disease severity according to the MELD score. Short term mortality following decompensation of chronic liver disease was not associated with hepatopulmonary syndrome.
\end{abstract}

HEADINGS - Hepatopulmonary syndrome. Liver diseases. Chronic disease. Inpatients.

\section{INTRODUCTION}

Hepatopulmonary syndrome (HPS) is defined as a clinical triad of liver disease, namely cirrhosis and/or portal hypertension, arterial deoxygenation and intrapulmonary vascular dilatations (IPVD) ${ }^{(6,9,12,17)}$. This syndrome is frequently underdiagnosed, due to the fact that most of the affected patients are either asymptomatic or present vague complaints of dyspnea and fatigue ${ }^{(13,16)}$. Depending on the criteria employed for its detection, HPS is reported to occur in $11 \%$ to $32 \%$ of the subjects with chronic liver disease (CLD), mainly cirrhotic patients ${ }^{(1,7,11,13,18)}$. Signs and symptoms of dyspnea, platypnea, spider nevi, cyanosis and finger clubbing are more frequent in patients with HPS when compared to their counterparts without HPS ${ }^{(13,17)}$. In addition, HPS was also related to more severe CLD, assessed either by the Child-Pugh (CP) score or by the Model for End-Stage Liver Disease (MELD) score, in some $^{(18)}$ but not all reports ${ }^{(1,10,13)}$.

Recently, the natural course of HPS was shown to be progressive ${ }^{(19)}$ and it was associated with shortened survival in patients awaiting orthotopic liver transplantation
$(\mathrm{OLT})^{(18)}$, as well as with increased mortality after $\mathrm{OLT}^{(3)}$. Mortality in those patients with CLD and HPS were mainly non-pulmonary and related to advanced CLD. In contrast, most of the deaths after OLT in HPS patients were attributed to cardiorespiratory complications ${ }^{(3)}$.

The purpose of the present study was to assess the frequency of HPS and its impact in survival of patients hospitalized with acute decompensation of CLD.

\section{METHODS}

\section{Patients}

All patients admitted to the Unit of Gastroenterology and Hepatology of the Portuguese Hospital of Salvador, BA, Brazil, from February 2003 to August 2005 with the diagnosis of acute decompensation of CLD were prospectively evaluated for the presence of HPS by arterial blood gas analysis, lung function tests and contrast enhanced echocardiography. Decompensation of CLD was characterized by the occurrence of variceal bleeding, hepatic encephalopathy, infections and tense ascites as well as any other acute clinical event requiring

Unit of Gastroenterology and Hepatology of the Portuguese Hospital of Salvador; ${ }^{2}$ School of Medicine of the Federal University of Bahia, Salvador, BA, Brazil. Correspondence: Dr. Paulo Lisboa Bittencourt - Rua Professor Clementino Fraga, 220 - apt.1901 - Ondina - Salvador, BA, Brazil. E-mail: plbbr@uol.com.br 
hospitalization. Patients with lower respiratory tract infections, massive pleural effusions and any other lung disease evidenced by chest $\mathrm{X}$ rays were excluded from the study. The diagnosis of CLD was based on clinical, biochemical and echographic findings, as well as on liver histology, whenever a liver biopsy specimen was available. The etiology of CLD and the reason for hospitalization was established in all patients. In the case of more than one cause for admission, the main cause was reckoned based on the following hierarchy: upper digestive bleeding, infection, hepatic encephalopathy, tense ascitis and others ${ }^{(5)}$. Clinical and biochemical parameters associated with CLD were sought in each patient. Severity of CLD was assessed by the Child-Pugh score $^{(15)}$ and the MELD score ${ }^{(22)}$.

Assessment of HPS was undertaken after initial clinical improvement and whenever the patient was able to perform diagnostic procedures for HPS. In the presence of tense ascites, removal of ascitic fluid by paracentesis was performed prior to the determination of HPS. Informed consent was obtained from the patients and the study protocol was approved by the Ethics Committee of the Portuguese Hospital.

Patients were followed until death or hospital discharge.

\section{Procedures}

Arterial blood gases analysis - One sample of blood was obtained by percutaneous radial artery puncture in a stable seated patient while breathing room air. Arterial pH, $\mathrm{O} 2$ and $\mathrm{CO} 2$ were measured using standard electrodes (Model ABL 700, Radiometer Medical, USA). The alveolar-arterial oxygen gradient ( $\mathrm{AaO} 2)$ was determined according to the alveolar gas equation ${ }^{(21) .}$ Hypoxemia and abnormal $\mathrm{AaO} 2$ were considered in the presence of $\mathrm{PO} 2$ of less than $80 \mathrm{~mm} \mathrm{Hg}$ and $\mathrm{AaO} 2$ levels of more than $15 \mathrm{~mm} \mathrm{Hg}$. In patients with more than 64 years, levels of $\mathrm{AaO} 2$ of more than $20 \mathrm{~mm} \mathrm{Hg}$ were considered abnormal ${ }^{(16)}$.

Pulmonary function tests - Standard pulmonary function tests were made in all patients three times using a portable spirometer (Microplus, MicroMedical Limited, USA) in order to assess functional vital capacity (FVC), forced expiratory volume at 1 second (FEV1), peak expiratory flow and the VEF1/FCV index.

Contrast enhanced echocardiography - The presence of pulmonary vascular dilatation was indirectly determined by qualitative assessment of right to left shunting using saline microbubble injection transthoracic contrast enhanced echocardiography (SONOS 2500, Hewlett Packard, Andover, MA, USA). Briefly, $20 \mathrm{~mL}$ of agitated $0.9 \%$ saline solution was injected in a peripheral intravenous line. After three to six heart beats, the identification of 60 to $90 \mu \mathrm{m}$ microbubbles in the left atrium by $\mathrm{CE}$ echocardiography, in the absence of intracardiac communications, was considered as evidence for IPVD technetium macroaggregated albumin lung perfusion scanning. In order to quantify the degree of IPVD, all patients with positive $\mathrm{CE}$ echocardiography were submitted to simultaneous technetium macroaggregated albumin (99mTcMAA) lung and brain scanning, as previously described ${ }^{(1,2)}$. Briefly, 20 minutes after injection of 2,5 mCI of 99mTcMAA (IPEN, Brazil; $90 \%$ of particle size in the range of 10 to $90 \mu \mathrm{m}$ ), quantitative brain imaging was performed in the supine position. Brain uptake was calculated using the geometric mean of technetium (GMT) counts in the brain and lungs, according to the following equation, assuming that $13 \%$ of the cardiac output is delivered to the brain:

Brain uptake (\%): (GMT brain/0.13) $\div($ GMT brain/0.13+ GMT lung)

Values higher than $6 \%$ were considered as positive. Shunting was graded as mild or moderate to severe based in the presence of brain uptake of less or more than $20 \%$, respectively.

Criteria for diagnosis of HPS - The diagnosis of HPS was considered in the presence of abnormal $\mathrm{AaO} 2$ and of pulmonary vascular dilatation assessed by CE echocardiography ${ }^{(18)}$. In addition, HPS severity was determined based on oxygenation abnormalities. Mild, moderate, severe and very severe HPS was considered in the presence of $\mathrm{PaO} 2$ equal or more than $80 \mathrm{~mm}$ $\mathrm{Hg}$; $\mathrm{PaO} 2$ less than $80 \mathrm{~mm} \mathrm{Hg}$ and equal or more than $60 \mathrm{~mm}$ $\mathrm{Hg}$; $\mathrm{PaO} 2$ less than $60 \mathrm{~mm} \mathrm{Hg}$ and equal or more than $50 \mathrm{~mm}$ $\mathrm{Hg}$ and $\mathrm{PaO} 2$ less than $50 \mathrm{~mm} \mathrm{Hg}$, respectively ${ }^{(18)}$.

\section{Statistical analysis}

The differences between groups of patients were compared using either the Kruskal-Wallis test or Chi-squared test or the Fisher exact probability test, when appropriate. A $P$ value $<0.05$ was considered significant. All statistical analysis were performed using SPSS for Windows, version 9 (SPSS Inc, Chicago, IL, USA). Clinical data are presented in text and tables as mean and standard deviation (SD).

\section{RESULTS}

One hundred and twenty five patients (98 males, mean age $62+11$ years) with the diagnosis of decompensated chronic liver disease were included in the study. Fifteen other patients admitted in the same time period could not be evaluated due to patient refusal $(n=3)$, death before the assessment of HPS $(\mathrm{n}=12)$.

Etiology of CLD was alcoholic liver disease in 67 (54\%) patients, hepatitis C virus infection in 43 (34\%) patients, cryptogenic cirrhosis in $12(10 \%)$ subjects, hepatitis B infection in $7(6 \%)$ patients and other causes in $13(10 \%)$ patients. The cause of admission was upper digestive bleeding in 33 (26\%) patients; infections, including spontaneous bacterial peritonitis and urinary tract infection in $40(32 \%)$ patients; hepatic encephalopathy in 19 patients $(15 \%)$, tense ascites in $22(18 \%)$ patients, and miscellaneous causes in $11(9 \%)$ patients.

Hypoxemia ( $\mathrm{PaO} 2$ less than $80 \mathrm{~mm} \mathrm{Hg}$ ) and abnormal $\mathrm{AaO} 2$ was observed, respectively, in 30 (24\%) and 107 (86\%) patients with decompensated CLD.

No major abnormality in pulmonary function tests was disclosed. Slight reduction of FVC was seen in 12 patients with tense ascites that resolved after paracentesis and mild reduction of FEV1/FVC ratio between 0.60 and 0.75 was disclosed in 16 subjects.

The presence of pulmonary vascular dilation and HPS was observed in $21(17 \%)$ and $19(15 \%)$ of the patients, respectively. Based on oxygenation parameters, eight $(6 \%)$ patients had mild 
HPS, nine (7\%) had moderate HPS, two (2\%) had severe HPS and none had very severe HPS.

All patients with HPS were further submitted to $99 \mathrm{mTcMAA}$ for shunting quantification. Twelve out of the $19(63 \%)$ patients with HPS had shunting by $99 \mathrm{mTcMAA}$ and all were graded as mild by scintigraphy ${ }^{(8)}$.

Clinical and laboratory features of the patients according to the presence of HPS are depicted in Table 1. Age and sex distribution, as well as etiology of CLD and its main cause for hospital admission were similar in subjects with and without HPS. The only clinical variables associated with HPS were presence of spider nevi (52\% of patients with HPS vs $25 \%$ of patients without HPS, $P=0.01)$ and digital clubbing $(16 \%$ of the patients with HPS vs $1 \%$ of the patients without HPS, $P=0.001)$. Symptoms and signs of dyspnea, platypnea and cyanosis were equally distributed in subjects with and without HPS.

Patients with HPS had significantly higher MELD scores when compared with patients without HPS $(19+7$ vs $15+6$, $P=0.02$ ). In contrast, CTP scores were not correlated with the presence of HPS. Twenty-seven patients died, 12 before

TABLE 1. Clinical and laboratory features of the patients according to the presence of HPS

\begin{tabular}{|c|c|c|c|}
\hline \multirow[b]{2}{*}{ Variables } & \multicolumn{2}{|c|}{ Patients } & \multirow[b]{2}{*}{$P$ value } \\
\hline & $\begin{array}{c}\text { without HPS } \\
(\mathrm{n}=106)\end{array}$ & $\begin{array}{c}\text { with HPS } \\
(\mathrm{n}=19)\end{array}$ & \\
\hline Age (years) & $62 \pm 11$ & $58 \pm 11$ & NS \\
\hline Male sex & $85(80 \%)$ & $13(68 \%)$ & NS \\
\hline \multicolumn{4}{|l|}{ Etiology of CLD } \\
\hline Alcoholic liver disease & $59(56 \%)$ & $8(42 \%)$ & NS \\
\hline Hepatitis C infection & $36(34)$ & $7(37)$ & NS \\
\hline Hepatitis B infection & $6(6)$ & $1(5)$ & NS \\
\hline Criptogenic cirrhosis & $11(10)$ & $1(5)$ & NS \\
\hline Others & $10(9)$ & $3(16)$ & NS \\
\hline \multicolumn{4}{|l|}{ Cause of decompensation } \\
\hline Upper digestive bleeding & $27(26)$ & $6(32)$ & NS \\
\hline Infections & $32(30)$ & $8(42)$ & NS \\
\hline Hepatic encephalopathy & $15(14)$ & $4(21)$ & NS \\
\hline Ascitis & $21(20)$ & $1(5)$ & NS \\
\hline Others & $11(10)$ & $0(0)$ & NS \\
\hline \multicolumn{4}{|l|}{ Clinical findings } \\
\hline Dyspnea & $37(35)$ & $7(37)$ & NS \\
\hline Platypnea & $32(30)$ & $6(32)$ & NS \\
\hline Spider nevi & $27(25)$ & $10(53)$ & 0,01 \\
\hline Digital clubbing & $1(1)$ & $3(16)$ & 0,001 \\
\hline \multicolumn{4}{|l|}{ Laboratory parameters } \\
\hline $\begin{array}{l}\text { Total bilirubin } \mathrm{mg} / \mathrm{dL} \\
(\text { normal < 1.1) }\end{array}$ & $3.3 \pm 4.6$ & $3.1 \pm 3.3$ & NS \\
\hline $\begin{array}{l}\text { Albumin g/dL } \\
\text { (normal: } 3.5-5.0 \text { ) }\end{array}$ & $2.4 \pm 0.6$ & $2.3 \pm 0.6$ & NS \\
\hline INR (normal: 1.0) & $1.5 \pm 0.4$ & $1.6 \pm 0.4$ & NS \\
\hline CTP score & $10 \pm 2$ & $11,0 \pm 2,1$ & NS \\
\hline MELD score & $16 \pm 6$ & $19 \pm 7$ & 0,02 \\
\hline \multicolumn{4}{|l|}{ Outcome } \\
\hline In hospital mortality & $12(11 \%)$ & $3(16)$ & NS \\
\hline
\end{tabular}

assessment of HPS. The main causes of death were liver failure $(\mathrm{n}=16)$; shock due to variceal bleeding $(\mathrm{n}=6)$ and septic shock $(\mathrm{n}=5)$. Mortality during hospitalization was not different in patients with and without HPS (Table 1). None of the patients were submitted to liver transplantation during hospitalization, due to liver allocation policies in Brazil based on duration of time on the waiting list.

\section{DISCUSSION}

This study demonstrated that $17 \%$ of the patients hospitalized for decompensated CLD had IPVD and 15\% had HPS. Most of the patients had mild to moderate HPS. Hypoxemia and abnormal $\mathrm{AaO} 2$ occurred more frequently, in $24 \%$ and $87 \%$ of the patients, respectively. These data are in accordance with previous reports that have found the presence of IPVD and HPS in $34 \%$ to $38 \%$ and $18 \%$ to $32 \%$ of the patients with CLD, using different cut-off levels of $\mathrm{PaO} 2$ and $\mathrm{AaO} 2$ for the definition of $\operatorname{HPS}^{(1,7,11,13,18)}$. As previously described ${ }^{(11,13)}$, patients with HPS in the present study had significantly more spider nevi and finger clubbing, when compared to their counterparts without HPS. In contrast, the higher frequency of dyspnea and platypnea, found in other reports concerning HPS patients, was not seen in the present study, possibly due to the fact that patients were interviewed during or just after hospital admission, due to complications of CLD that may be associated respiratory symptoms or with impaired consciousness, like sepsis, tense ascites and hepatic encephalopathy.

Patients with HPS in this study had more severe liver disease assessed by the MELD score, but not by CP classification. This is not unexpected, since most of our patients with decompensated CLD had high CP scores. In those subjects it is noteworthy that the MELD score correlates better with severity and with patient mortality due to CLD. The MELD score is currently employed in the United States of America as criteria for severity of CLD and for allocation of organs for liver transplantation. Several other studies have found no association of mild to severe HPS with severity of $\operatorname{CLD}^{(1,10,11,13)}$, but it is worth to mention that disease severity in those reports was assessed in only by the CP and not by the MELD score.

Recently, SCHENK et al. ${ }^{(18)}$ found an association of HPS and severity of liver disease. The authors have investigated HPS in ambulatory patients with compensated CLD. They have found more severe CLD assessed either by the CP or the MELD score in patients with CLD. Furthermore, the authors have found shortened survival of patients with HPS, when compared to counterparts without HPS (median survival 10.6 months with HPS vs. 40.8 months without HPS). In this cohort, HPS was one of the variables, besides age, CP class and blood urea nitrogen, that were independently associated with survival ${ }^{(18)}$.

Similar data was also found in subjects with HPS submitted to OLT in some ${ }^{(3)}$ but not all reports(4, 20). In this respect, increased mortality after OLT was linked to HPS, particularly in subjects with $\mathrm{PaO} 2$ equal or less than $50 \mathrm{~mm} \mathrm{Hg}$ and/or with 99 mTcMAA shunt fraction more than $20 \%{ }^{(3)}$. Based in these findings and in the progressive natural course of HPS, 
several authorities recommend early referral of those patients to liver transplantation ${ }^{(12,14)}$.

In the present study concerning a different subset of patients with decompensated CLD, we were unable to find any influence of HPS in patient short-term mortality during the hospitalization period. However, it is worth to mention that 12 patients died before an attempt for their inclusion in the present study and this could have influenced our results concerning the effect of HPS on patient mortality.

In summary, $17 \%$ of the patients hospitalized due to complications of CLD had HPS. Spider nevi and finger clubbing were clinical signs associated with the syndrome.
More advanced CLD assessed by the MELD score was seen in HPS affected patients. No influence of HPS in shortterm patient survival was seen during the hospitalization time period.

\section{ACKNOWLEDGEMENTS}

The authors would like to thank Dr. Daniel Simões May for statistical analysis as well as Ms. Marcia Cristina Lacerda dos Santos for assistance with the preparation of the submitted manuscript.

Ferreira PP, Camara EJN, Paula RLP, Zollinger CC, Cavalcanti AR, Bittencourt PL. Prevalência da síndrome hepatopulmonar e seu impacto na sobrevida de pacientes hospitalizados com doença parenquimatosa crônica descompensada de fígado. Arq Gastroenterol. 2008;45(1):34-7.

RESUMO - Racional - A síndrome hepatopulmonar ocorre em 4\% a 32\% dos pacientes com doença crônica parenquimatosa do fígado e está associada à gravidade da doença hepática e menor sobrevida antes e após o transplante hepático. Objetivos - Avaliar a freqüência da síndrome hepatopulmonar em pacientes brasileiros hospitalizados com doença crônica parenquimatosa do fígado descompensada e investigar o seu impacto na sobrevida intra-hospitalar. Métodos - Cento e trinta doentes (101 homens, idade média $61 \pm 12$ anos) com doença crônica parenquimatosa do fígado descompensada foram avaliados quanto à presença de síndrome hepatopulmonar. O diagnóstico de síndrome hepatopulmonar foi considerado na presença de aumento do gradiente alvéolo arterial de oxigênio maior que $15 \mathrm{~mm} \mathrm{Hg}$ e de dilatação vascular pulmonar avaliada pelo ecocardiografia com microbolhas. Resultados - Síndrome hepatopulmonar foi observada em 21 (16\%) dos doentes. Sua presença foi associada à gravidade da doença hepática avaliada pela pontuação MELD, mas não com mortalidade intra-hospitalar. Conclusões - A síndrome hepatopulmonar ocorre em 16\% dos pacientes hospitalizados com doença crônica parenquimatosa do fígado, estando associada à gravidade da doença hepática. Mortalidade a curto prazo por descompensação da doença crônica parenquimatosa do fígado não foi associada à presença de síndrome hepatopulmonar.

DESCRITORES - Síndrome hepatopulmonar. Hepatopatias. Doença crônica. Pacientes internados.

\section{REFERENCES}

1. Abrams GA, Jaffe CC, Hoffer PB, Binder HJ, Fallon MB. Diagnostic utility of contras echocardiography and lung perfusion scan in patients with hepatopulmonary syndrome. Gastroenterology. 1995;109:1283-8.

2. Abrams GA, Nanda NC, Dubovsky EV, Krowka MJ, Fallon MB. Use of macroaggregated albumin lung perfusion scan to diagnose hepatopulmonary syndrome: a new approach. Gastroenterology. 1998;114:305-10.

3. Arguedas MR, Abrams GA, Krowka MJ, Fallon MB. Prospective evaluation of outcomes and predictors of mortality in patients with hepatopulmonary syndrome undergoing liver transplantation. Hepatology. 2003;37:192-7.

4. Collisson EA, Nourmand H, Fraiman MH, Cooper CB, Bellamy PE, Farmer DG, Vierling JM, Ghobrial RM, Busuttil RW. Retrospective analysis of the results of liver transplantation for adults with severe hepatopulmonary syndrome. Liver Transpl. 2002;8:925-31

5. Fernandez J, Navasa M, Gomez J, Colmenero J, Vila J, Arroyo V, Rodes J. Bacterial infections in cirrhosis: epidemiological changes with invasive procedures and norfloxacin prophylaxis. Hepatology. 2002;35:140-8.

6. Gaines DI, Fallon MB. Hepatopulmonary syndrome. Liver Int. 2004;24:397-401.

7. Gupta D, Vijaya DR, Gupta R, Dhiman RK, Bhargava M, Verma J, Chawla YK. Prevalence of hepatopulmonary syndrome in cirrhosis and extrahepatic portal venous obstruction. Am J Gastroenterol. 2001;96:3395-9.

9. Hiroto E, Mureo K, Yukiko I, Shinji U, Kastsuhiko A, Siro F, Tetsuya K, Michihiro H, Toshiya Y, Muneo Y, Yasuhiko A, James AMS, Koichi T. Long-term outcome of living related liver transplantation for patients with intrapulmonary shunting and strategy for complications. Transplantation. 1999;67:712-7.

10. Hoeper MM, Krowka MJ, Strassburg CP. Portopulmonary hypertension and hepatopulmonary syndrome. Lancet. 2004;1:1461-8.

11. Krowka MJ, Wiseman GA, Burnett OL, Spivey JR, Therneau T, Porayko MK, Wiesner RH. Hepatopulmonary syndrome: a prospective study of relationships between severity of liver disease, $\mathrm{PaO}(2)$ response to $100 \%$ oxygen, and brain uptake after $(99 \mathrm{~m}) \mathrm{Tc}$ MAA lung scanning. Chest. 2000;118:615-24.
12. Lima BLG, França AVC, Pazin-Filho A, Araújo WM, Martinez JAB, Maciel BC, Simões MV, Terra-Filho J, Martinelli ALC. Frequency, clinical characteristics, and respiratory parameters of hepatopulmonary syndrome. Mayo Clin Proc. 2004;79:42-8.

13. Mandell MS. Hepatopulmonary syndrome and portopulmonary hypertension in the model for end-stage liver disease (MELD) era. Liver Transpl. 2004;10:s54-8.

14. Martinez GP, Barbera JA, Visa BJ, Rimola A, Pare JC, Roca J, Navasa M, Rodes J, Rodriguez- Roisin R. Hepatopulmonary syndrome in candidates for liver transplantation. J Hepatol. 2001;34:651-7.

15. Murray KF, Carithers RL Jr. AASLD practice guidelines: evaluation of the patient for liver transplantation. Hepatology. 2005;41:1407-32.

16. Pugh RN, Murray-Lyon M, Dawson JL, Pietroni C, Williams R. Transection of the oesophagus for bleeding oesophageal varices. Br J Surg. 1973;60:646-9.

17. Rodrigez-Roisin R, Krowka MJ, Herve Ph, Fallon MB. Pulmonary-hepatic vascular Disorders (PHD). Eur Respir J. 2004;24:861-80.

18. Rodrigez-Roisin R, Krowka MJ, Herve Ph, Fallon MB. Highlights of the ERS task force on pulmonary-hepatic vascular disorders (PHD). J Hepatol. 2005;42:924-7.

19. Schenk P, Schoniger-Hekele M, Fuhrmann V, Nadl C, Silberhumer G, Muller C. Prognostic significance of the hepatopulmonary syndrome in patients with cirrhosis. Gastroenterology. 2003;125:1042-52.

20. Swanson KL, Wiesner RH, Krowka MJ. Natural history of hepatopulmonary syndrome: impact of liver transplantation. Hepatology. 2005;41:1122-9.

21. Taille C, Cadranel J, Bellocq A, Thabut G, Soubrane O, Durand F, Ichai P, Duvoux C, Belghiti J, Calmus Y, Mal H. Liver transplantation for hepatopulmonary syndrome: a ten-year experience in Paris, France. Transplantation. 2003;75:1482-9.

22. West JB. Pulmonary pathophsiology-the essentials. $4^{\text {th }}$ ed. Baltimore: Williams and Wikins; 1990.

23. Wiesner R, Edwards E, Freeman R, Harper A, Kim R, Kamath P. Model for endstage liver disease (MELD) and allocation of donor livers. Gastroenterology 2003;124:91-6. 